\title{
PENERAPAN PENDEKATAN REALISTIC MATHEMATICS EDUCATION (RME) TERHADAP KEMAMPUAN PEMAHAMAN KONSEP MATEMATIS
}

\author{
Arnida Sari ${ }^{1}$, Suci Yuniati ${ }^{2}$ \\ 1,2 Jurusan Pendidikan Matematika, Universitas Islam Negeri Sultan Syarif Kasim Riau \\ Email penulis pertama: arnidasari@uin-suska.ac.id
}

\begin{abstract}
This study to examine whether there are differences in the ability to understand mathematical Concepts between students who learn to use realistic mathematics education (RME) approach with students who learn to use conventional method. This research type is Quasi Experimental Design research. The design used is the Postest Only Control Design. The result showed that the average difference using t-test was better in the experimental class than in the control class. Thus it can be concluded that there are differences in the ability understand mathematical concepts between students who learn to use realistic mathematics education (RME) approach with students who learn to use conventional methods.
\end{abstract}

Keywords: Mathematics Learning, RME approach, understanding mathematical Concepts

\begin{abstract}
Abstrak
Penelitian ini bertujuan untuk menguji apakah terdapat perbedaan kemampuan pemahaman konsep antara siswa yang belajar menggunakan pendekatan realistic mathematics education (RME) dengan siswa yang belajar menggunakan metode konvensional. Jenis Penelitian ini adalah penelitian Quasi Eksperimental Design. Desain yang digunakan adalah Postest Only Control Design. Hasil penelitian menunjukan bahwa perbedaan rata-rata menggunakan uji t lebih baik di kelas eksperimen daripada di kelas kontrol. Dengan demikian dapat disimpulkan bahwa terdapat perbedaan kemampuan pemahaman konsep antara siswa yang belajar menggunakan pendekatan realistic mathematics education (RME) dengan siswa yang belajar menggunakan metode konvensional.
\end{abstract}

Kata kunci: Pembelajaran Matematika, Pendekatan RME, Pemahaman Konsep Matematis

Proses pembelajaran dikatakan efektif apabila siswa dilibatkan langsung secara aktif untuk berusaha dan mencari pengalaman serta menghubungkan informasi yang diperolehnya tentang matematika. Dalam proses pembelajaran, guru perlu juga memfasilitasi serangkaian kegiatan yang memberi ruang bagi siswa untuk terjadinya interaksi sosial. Siswa terlibat langsung secara aktif dalam membangun makna matematika bagi dirinya, baik secara individual maupun kelompok. Dengan demikian proses pembelajaran yang dilakukan di kelas diharapkan dapat memberikan dorongan atau motivasi bagi siswa dalam mengembangkan aktifitasnya di kelas. Pentingnya kemampuan pemahaman konsep ini juga sejalan dengan peraturan Menteri Pendidikan dan Kebudayaan Nomor 58 Tahun 2014 bahwa tujuan pembelajaran matematika adalah sebagai berikut :

1. Memahami konsep matematika, merupakan kompetensi dalam menjelaskan keterkaitan antarkonsep dan menggunakan konsep maupun algoritma, secara luwes, akurat, efisien, dan tepat, dalam pemecahan masalah.

2. Menggunakan pola sebagai dugaan dalam penyelesaian masalah, dan mampu membuat generalisasi berdasarkan fenomena atau data yang ada.

3. Menggunakan penalaran pada sifat, melakukan manipulasi matematika baik dalam 
penyederhanaan, maupun menganalisa komponen yang ada dalam pemecahan masalah dalam konteks matematika maupun di luar matematika (kehidupan nyata, ilmu, dan teknologi) yang meliputi kemampuan memahami masalah, membangun model matematika, menyelesaikan model dan menafsirkan solusi yang diperolehtermasuk dalam rangka memecahkan masalah dalam kehidupan sehari-hari (dunia nyata).

4. Mengkomunikasikan gagasan,penalaran serta mampu menyusun bukti matematika dengan menggunakan kalimat lengkap, simbol, tabel, diagram, atau media lain untuk memperjelas keadaan atau masalah.

5. Memiliki sikap menghargai kegunaan matematika dalam kehidupan, yaitu memiliki rasa ingin tahu, perhatian, dan minat dalam mempelajari matematika, serta sikap ulet dan percaya diri dalam pemecahan masalah.

6. Memiliki sikap dan perilaku yang sesuai dengan nilai-nilai dalam matematika dan pembelajarannya, seperti taat azas, konsisten, menjunjung tinggi kesepakatan, toleran, menghargai pendapat orang lain, santun, demokrasi, ulet, tangguh, kreatif, menghargai kesemestaan (konteks, lingkungan), kerjasama, adil, jujur, teliti, cermat, bersikap luwes dan terbuka, memiliki kemauan berbagi rasa dengan orang lain.

7. Melakukan kegiatan-kegiatan motorik yang menggunakan pengetahuan matematika

8. Menggunakan alat peraga sederhana maupun hasil teknologi untuk melakukan kegiatankegiatan matematika.

Oleh karena itu, kemampuan pemahaman konsep matematis adalah salah satu tujuan penting dalam pembelajaran matematika. Namun kenyataannya kemampuan pemahaman konsep matematis siswa masih tergolong rendah. Rendahnya kemampuan pemahaman konsep matematis siswa ini akan mempengaruhi kualitas belajar siswa yang berdampak pula pada rendahnya prestasi belajar siswa disekolah.

Fakta di lapangan menunjukkan bahwa proses pembelajaran di kelas cenderung berlangsung secara teoritis. Situasi tersebut berdampak pada siswa yang cenderung menghafal dan menganggap bahwa matematika adalah suatu masalah yang besar ketika siswa dihadapkan pada materi yang sangat sulit. Selain itu, siswa tidak menemukan suatu konsep untuk memahami materi yang diajarkan, akibatnya sesuatu yang dipahami oleh siswa hanyalah bersifat sementara. Hal ini membuktikan bahwa pemahaman siswa terhadap konsep-konsep yang dipelajari belum tercapai, sehingga menyebabkan pembelajaran menjadi tidak efektif dan bermuara pada rendahnya persentase ketuntasan belajar. Dari sisi lain matematika sebagai ilmu pengetahuan yang bersifat abstrak, menyebabkan siswa tidak tertarik untuk mempelajari bahkan dianggap sebagai mata pelajaran yang paling membosankan. Sebagai akibat dari kondisi seperti itu maka hasil belajar matematika di sekolah-sekolah, baik di sekolah dasar maupun di sekolah menengah masih relatif rendah dibandingkan dengan hasil belajar siswa untuk bidang studi yang lain.

Kemampuan pemahaman matematik Kemampuan pemahaman matematik dalam penelitian ini 
adalah kemampuan pemahaman menurut Skemp yaitu (1) pemahaman instrumental dimana siswa mampu menghapal rumus/prinsip, dapat menerapkan rumus dalam perhitungan sederhana dan mengerjakan pehitungan secara algoritmik; (2) pemahaman relasional, dimana siswa mampu mengaitkan sesuatu dengan hal lainnya secara benar serta menyadari prosesnya.

W. S. Winkel mengartikan konsep sebagai suatu sistem satuan arti yang mewakili sejumlah objek yang mempunyai ciri-ciri yang sama dan Gagne menyatakan bahwa konsep adalah suatu ide abstrak yang memungkinkan kita dapat mengelompokkan objek ke dalam contoh dan non contoh. Jadi, pemahaman konsep merupakan hasil pemikiran dan kemampuan seseorang dalam mengembangkan ide abstrak, mengelompokkan obyek sesuai dengan cirinya. Pemahaman konsep ini meliputi mendeskripsikan dengan kata-kata sendiri, membedakan dan membandingkan, mengetahui hubungan antar konsep dan antar data serta menarik kesimpulan.

Berdasarkan Badan Standar Nasional Pendidikan (BNSP) dalam model penilaian kelas pada satuan SMP menyebutkan indikator-indikator yang menunjukkan pemahaman konsep antara lain:

1) Menyatakan ulang sebuah konsep, yaitu kemampuan siswa untuk mengungkapkan kembali apa yang telah dikomunikasikan kepadanya baik lisan maupun tulisan.

2) Mengklasifikasikan objek menurut sifat-sifat tertentu sesuai dengan konsepnya, yaitu kemampuan siswa untuk dapat mengelompokkan objek menurut sifat-sifatnya.

3) Memberi contoh dan non contoh dari konsep, yaitu kemampuan siswa dapat membedakan contoh dan bukan contoh dari suatu materi yang telah dipelajari.

4) Menyajikan konsep dalam berbagai bentuk representasi matematis, yaitu kemampuan siswa menggambar atau membuat grafik, membuat ekspresi matematis, menyusun cerita atau teks tertulis.

5) Mengembangkan syarat perlu atau syarat cukup dari suatu konsep, yaitu kemampuan siswa mengkaji mana syarat perlu atau syarat cukup suatu konsep yang terkait.

6) Menggunakan, memanfaatkan, dan memilih prosedur tertentu, yaitu kemampuan siswa menyelesaikan soal dengan tepat sesuai dengan prosedur.

7) Mengaplikasikan konsep atau algoritma pemecahan masalah, yaitu kemampuan siswa menggunakan konsep atau prosedur tertentu.

Berdasarkan uraian tersebut dapat disimpulkan bahwa pemahaman konsep matematika adalah kemampuan bersikap, berpikir dan bertindak yang ditunjukkan oleh siswa dalam memahami definisi, pengertian, ciri khusus, hakikat dan inti atau isi dari materi matematika dan kemampuan dalam memilih serta menggunakan prosedur secara efisien dan tepat. Pemahaman konsep materi prasyarat sangat penting untuk memahami konsep selanjutnya. Selain itu pemahaman konsep dapat digunakan untuk menggeneralisasikan suatu objek. 
Susanto di dalam Fadhila (2014) menyatakan kemampuan pemahaman konsep merupakan kemampuan siswa untuk dapat mengerti konsep yang diajarkan guru. Lebih lanjutnya menurut Fadhila kemampuan siswa dalam menjelaskan konsep yang telah dipelajari dengan menggunakan kata-kata sendiri.

Berdasarkan hasil observasi penelti terhadap hasil belajar siswa, terutama pada aspek pemahaman konsep matematika di MTs Danau Bingkuang Kampar, mengatakan banyak siswa yang beranggapan bahwa pelajaran matematika adalah salah satu mata pelajaran yang sulit, yang dilihat dari pemahaman konsep matematika siswa masih tergolong rendah, dengan gejala-gejala sebagai berikut:

1. Sebagian besar siswa belum bisa memilih prosedur atau operasi yang sesuai dalam menyelesaikan soal.

2. Jika diberikan soal cerita, siswa belum bisa mengaplikasikan konsep yang telah diajarkan.

3. Jika guru memberikan soal yang modelnya sedikit berbeda dari contoh, sebagian besar siswa mengalami kesulitan dalam menyelesaikannya.

4. Jika guru menanyakan kembali tentang materi pelajaran matematika sebelumnya, sebagian besar siswa sering tidak dapat menjawab.

5. Masih ada sebagian siswa yang belum paham dengan persoalan yang ada pada soal, seperti tidak bisa menemukan apa yang diketahui dan yang ditanya dalam soal.

Dari gejala-gejala tersebut, guru matematika MTs Danau Bingkuang telah melakukan beberapa usaha untuk meningkatkan pemahaman konsep matematika siswa diantaranya menerapkan pembelajaran menggunakan metode ceramah, tanya jawab, diskusi kelompok dan pemberian tugas.

Pada tahun 1973, Freudental memperkenalkan suatu model baru dalam pembelajaran matematika yang dikenal dengan nama Realistic Mathematics Education atau istilah lain yaitu PMR (Pembelajaran Matematika Realistik). Realistic Mathematics Education (RME) awalnya dikembangkan di negeri Belanda (Andriani dkk, 2013:44). Menurut Wijaya (2012:3) pendekatan RME berlandaskan pada filosofi matematika sebagai aktivitas manusia (mathematics as human activity) yang dicetuskan oleh Hans Freudental. Maksudnya adalah bahwa matematika bukan suatu produk melainkan sebagai suatu proses atau bentuk aktivitas. Menurut Saleh (2012: 51) pendekatan pembelajaran matematika realistik adalah suatu pembelajaran berfokus pada masalah yang dapat dibayangkan siswa sebagai masalah dalam kehidupan nyata atau masalah dalam dunia mereka. Pendekatan Pembelajaran Matematika Realistik adalah salah satu pendekatan yang dikembangkan untuk semakin mendekatkan siswa dengan matematika (Prabowo dan Sidi, 2010:9). Siswa akan merasakan dekat dengan matematika karena siswa mengalami sendiri dalam kehidupan nyata sehingga belajar matematika akan terasa lebih bermakna.

Terdapat lima prinsip utama dalam kurikulum matematika realistik, kelima prinsip tersebut adalah sebagai berikut (Suherman, 2003:128): (1) didominasi oleh masalah-masalah dalam konteks, melayani dua hal yaitu sebagai sumber dan sebagai terapan konsep matematika, (2) perhatian 
diberikan pada pengembangan model-model, situasi, skema, dan simbol-simbol, (3) sumbangan dari para siswa, sehingga siswa dapat memebuat pembelajaran menjadi konstruktif dan produktif, artinya siswa memproduksi sendiri dengan mengkontruksi sendiri (yang mungkin berupa algoritma, rule, atau aturan), sehingga dapat membimbing para siswa dari level matematika informal manuju matematika formal, (4) interaktif sebagai karakteristik dari proses pembelajaran matematika, dan (5) 'intertwining' (membuat jalinan atau menghubungkan) antar topik atau antar pokok bahasan atau antar 'strand'.

Berdasarkan penjelasan di atas, dapat disimpulkan bahwa pendekatan Realistic Mathematics Education merupakan suatu pendekatan proses pembelajaran matematika yang bermula dari dunia nyata untuk mengembangkan konsep-konsep, ide-ide matematika serta menyatukan matematika dalam kehidupan sehari-hari sehingga pembelajaran dengan menggunakan pendekatan ini akan menjadi lebih bermakna dan tentunya akan lama diingat oleh siswa. Berdasarkan hasil penelitian Atika dan Zubaidah (2018) pengembangan LKS berbasis pendekatan RME untuk menumbuhkembangkan kemampuan berpikir kritis matematis siswa dan Erna Siti Nur'aini, Riana Irawati dan Julia (2016) dalam penelitiannya pengaruh pendekatan realistic mathematics education (RME) terhadap Kemampuan Pemahaman Matematis dan Kepercayaan Diri Siswa pada Materi Menyederhanakan Pecahan. Sedangkan Penelitian sebelum ini penulis telah mengembangkan modul matematika terintegrasi nilai-nilai keislaman melalui pendekatan realistic Mathematics Education (RME) di Provinsi Riau. Sehingga berdasarkan penelitian tersebut penulis dapat menyimpulkan bahwa pendekatan RME ini dapat mempengaruhi kemampuan pemahaman konsep matematis siswa. Fakta lain dari hasil penelitian yang dilakukan oleh Aan Hendrayana (2017) mengatakan bahwa kemampuan pemahaman konsep matematis siswa SMP masih belum seperti yang diharapkan, siswa masih bingung jika dihadapkan dengan persoalan luas jajargenjang kemudian mereka tidahafal rumus mencari luasnya. Nela Rizka, Hendra Syarifuddin dan Suherman. (2014) meneliti pengaruh penerapan strategi relating, experiencing, appliying, cooperating, transferring terhadap kemampuan pemahaman konsep matematika siswa kelas X SMAN 2 payakumbuh. Sedangkan Hayatun Nufus dan penelitian Saraswati dkk (2012) Penerapan pembelajaran two stay two stray (TSTS) dapat mempengaruhi kemampuan pemahaman konsep dan minat. Sedangkan menurut Suci Yuniati (2015) dalam penelitiannya yang berjudul pengaruh penerapan pendekatan realistic mathematics education terhadap kemampuan koneksi matematika siswa madrasah tsanawiyah pondok pesantren darel hikmah pekanbaru, penggunaan pendekatan ini efisien untuk tingkat menengah pertama. Berdasarkan penelitian-penelitian tersebut penulis melaksanakan penelitian ke sekolah dengan menggunakan pendekatan realistic mathematics education terhadap kemampuan pemahaman matematis siswa di tingkat SMP/MTs. 


\section{METODE}

Jenis dan Desain Penelitian

Penelitian ini menggunakan pendekatan eksperimen dengan penelitian dalam bentuk posttest Only Control Design, yaitu desain kelompok kontrol postes yang melibatkan dua kelompok dan pengambilan sampel dilakukan secara acak kelas. Sedangkan pemilihan sekolah dilakukan dengan purposive sampling.

Berdasarkan desain ini terdapat dua kelompok yang dipilih secara langsung. Kelompok pertama diberi perlakuan $(\mathrm{X})$ dan kelompok yang lain tidak. Kelompok yang diberi perlakuan disebut kelompok eksperimen dan kelompok yang tidak diberi perlakuan disebut kelompok kontrol. Secara rinci desain Posttest Only Control Design dapat dilihat pada Tabel III.1:

\section{Tabel 1}

Posttest Only Control Design

\begin{tabular}{|c|c|c|}
\hline Kelas & Perlakuan & Posttest \\
\hline Eksperimen & $\mathrm{X}$ & $\mathrm{O}_{1}$ \\
\hline Kontrol & - & $\mathrm{O}_{2}$ \\
\hline
\end{tabular}

Sumber: Endang Mulyantiningsih, model penelitian Terapan Bidang Pendidikan

Keterangan:

$\mathrm{X}=$ Perlakuan pada kelas eksperimen

$\mathrm{O}_{1}=$ Pretes kelas kontrol

$\mathrm{O}_{2}=$ Postes kelas kontrol

\section{Waktu, Tempat dan Subjek Penelitian}

Penelitian ini dilaksanakan pada semester ganjil tahun ajaran 2016/2017 bulan 18 September s.d 21 Oktober 2017 Penelitian menyesuaikan jadwal pelajaran semester ganjil yang ada di sekolah tersebut. Untuk Sampel dalam penelitian ini adalah kelas VII MTs Negeri Danau Bingkuang. Kelas VII.1 sebagai kelas eksperimen dan kelas VII.2 sebagai kelas kontrol dengan masing-masing jumlah siswa adalah 31 orang. Instrumen Penelitian dan Teknik Pengumpulan Data Pengambilan sampel dipilih dua lokal yaitu Kelas VII.1 dan VII.2 dengan menggunakan teknik purposive sampling. Purposive Sampling yaitu teknik pengambilan sampel dengan memikirkan pertimbangan tertentu (Sugiyono, 2013). Adapun teknik pengumpulan data pada penelitian ini yaitu dengan melakukan pengamatan atau observasi, tes pemahaman matematis dan dokumentasi. Pengamatan atau observasi dilakukan oleh guru dengan cara menggunakan instrumen yang sudah dirancang sebelumnya. Teknik observasi menggunakan lembar pengamatan guru dan siswa untuk mengamati kegiatan guru dan siswa yang diharapkan muncul dalam pembelajaran matematika dengan pendekatan RME yang dilakukan setiap kali pertemuan. Untuk mengukur kemampuan pemahaman matematis siswa pada penelitian ini menggunakan tes berbentuk uraian dengan cara memberikannya pada kedua kelas sampel setelah diberi perlakuan. Sebelum tes dilakukan, soal tes harus terlebih dulu diuji sehingga memenuhi 
beberapa syarat seperti validitas, reliabilitas, daya pembeda dan tingkat kesukaran soal. Sedangkan dokumentasi digunakan untuk memperoleh data langsung dari tempat penelitian dan data yang relevan dengan penelitian ini.

\section{Teknik Analisis Data}

Setelah soal tes diujicobakan, maka tahap selanjutnya adalah menganalisis hasil uji coba instrument tersebut yang meliputi:

\section{Validitas}

Suatu instrumen dikatakan valid apabila instrumen tersebut dapat mengukur secara tepat sesuai dengan keadaan yang sebenarnya. Validitas adalah suatu ukuran yang menunjukkan tingkat-tingkat kesahihan suatu instrumen (Hartono, 2010). Dalam menentukan validitas digunakan rumus Korelasi Product Moment.

Hasil dari analisis validasi soal yang menunjukkan tingkat-tingkat kesahihan soal dapat dilihat pada Tabel 2.

Tabel 2 Hasil Validitas Soal

\begin{tabular}{ccccc}
\hline $\begin{array}{c}\text { No. } \\
\text { Item } \\
\text { Soal }\end{array}$ & $\begin{array}{c}\text { Koefisien Korelasi } \\
\boldsymbol{r}_{\text {hitung }}\end{array}$ & $\begin{array}{c}\text { Harga } \\
\boldsymbol{t}_{\text {hitung }}\end{array}$ & Harga $\boldsymbol{t}_{\text {tabel }}$ & Keputusan \\
\hline $\mathbf{1}$ & 0,680 & 3,928 & 1,734 & Valid \\
\hline $\mathbf{2}$ & 0,672 & 3,85 & 1,734 & Valid \\
\hline $\mathbf{3}$ & 0,607 & 3,301 & 1,734 & Valid \\
\hline $\mathbf{4}$ & 0,523 & 2,603 & 1,734 & Valid \\
\hline $\mathbf{5}$ & 0,704 & 4,204 & 1,734 & Valid \\
\hline
\end{tabular}

Dari tabel dapat dilihat bahwa dari lima soal yang diujicobakan, semua soalnya diuji telah valid. Oleh karena itu, tes tersebut layak digunakan sebagai instrumen penelitian.

\section{Reabilitas}

Reliabilitas adalah tingkat atau derajat konsistensi dari suatu instrument (Arifin, 2012). Pengukuran reabilitas dengan yaitu menggunakan rumus Alpha. Berdasarkan hasil uji coba reliabilitas butir soal secara keseluruhan diperoleh koefisien reliabilitas tes sebesar 0,7021. Jika dibandingkan dengan nilai $r_{\text {tabel }} 0,436$, berarti Harga $r_{\text {hitung }}>r_{\text {tabel }}$ atau $0,7021>0,436$, maka keputusan seluruh butir soal adalah reliabel dengan kriteria "tinggi".

\section{Taraf Kesukaran}

Perhitungan tingkat kesukaran soal adalah pengukuran seberapa besar derajat kesukaran suatu soal (Suharsimi, 2011). 


\section{Tabel 3}

\section{Hasil Perhitungan Tingkat Kesukaran Soal}

\begin{tabular}{ccc}
\hline No. & Tingkat Kesukaran Soal & Interpretasi \\
\hline $\mathbf{1}$ & 0,31 & Sedang \\
\hline $\mathbf{2}$ & 0,517 & Sedang \\
\hline $\mathbf{3}$ & 0,55 & Sedang \\
\hline $\mathbf{4}$ & 0,283 & Sukar \\
\hline $\mathbf{5}$ & 0,617 & Sedang \\
\hline
\end{tabular}

\section{Daya Pembeda}

Perhitungan daya pembeda adalah pengukuran sejauh mana suatu butir soal mampu membedakan peserta didik yang belum atau kurang menguasai kompetensi berdasarkan kriteria tertentu (Suharsimi, 2011).

\section{Tabel 4}

\section{Hasil Perhitungan Daya Pembeda Soal}

\begin{tabular}{ccc}
\hline Nomor Soal & Daya Pembeda & Interpretasi \\
\hline $\mathbf{1}$ & 0,4 & Baik $($ good $)$ \\
\hline $\mathbf{2}$ & 0,3 & Cukup (satisfactory) \\
\hline $\mathbf{3}$ & 0,5 & Baik $($ good $)$ \\
\hline $\mathbf{4}$ & 0,22 & Cukup $($ satisfactory) \\
\hline $\mathbf{5}$ & 0,4 & Baik $($ good $)$ \\
\hline
\end{tabular}

Berdasarkan hasil analisis terhadap validitas, reliabilitas, tingkat kesukaran dan daya pembeda soal, dapat disimpulkan bahwa tes yang telah diujicobakan dapat digunakan sebagai instrumen pada penelitian ini.

\section{HASIL DAN PEMBAHASAN}

Dari hasil pengujian yang diperoleh setelah data dianalisis, menunjukkan bahwa terdapat perbedaan antara kemampuan pemahaman konsep matematis siswa yang menggunakan pendekatan realistic mathematics education (RME) dengan siswa yang belajar menggunakan pembelajaran konvensional. Adanya perbedaan menunjukkan pendekatan realistic mathematics education (RME) berpengaruh terhadap kemampuan pemahaman konsep matematis siswa. Hasil dan peningkatan hasil belajar siswa di kelas eksperimen cenderung lebih baik dan lebih aktif jika dibandingkan dengan kelas kontrol. Hal ini dapat disimpulkan bahwa penerapan pendekatan realistic mathematics education (RME) dalam pembelajaran matematika memiliki pengaruh positif terhadap kemampuan pemahaman konsep matematis.

Siswa pada kelas eksperimen lebih menonjolkan pembelajarannya berdasarkan kehidupan sehari-hari yang mereka ketahui, sehingga mereka dengan mudah dan aktif dalam menyelesaikan pembelajaran disebabkan konsep dasar pembelajaran sudah seuai dengan pengetahuan mereka. 
Penggunaan pendekatan realistic mathematics education (RME) berdasarkan analisis kebutuhan siswa akan materi dan cara pembelajaran yang sesuai dengan dasar pemahaman mereka. Sehingga dapat dijelaskan bahwa siswa yang berada pada kelas eksperimen lebih mudah meyerap pelajaran dan menyelesaikan soal dengan baik. Sesuai dengan analisis penulis bahwa terdapat perbedaan kemampuan pemahaman konsep matematis siswa yang belajar menggunakan pendekatan realistic mathematics education (RME) dengan siswa yang belajar dengan metode konvensional.

Penelitian ini masih banyak kelemahan dan keterbatasan yang sulit dikendalikan. Adapun keterbatasan pada saat penelitian yaitu: siswa cenderung awam untuk menghubungkan kegiatan sehari-harinya ke dalam masalah matematika, sehingga ketika guru mengubah konsep matematis mereka kurang cepat menerima, harus mengulang-ulang konsep matematis yang mereka dapatkan sebelum menggunakan pendekatan realistic mathematics education (RME). Namun demikian, keterbatasan penelitian ini tidak mengurangi kebenaran hasil penelitian yang diperoleh, sehingga dapat dipergunakan dalam meningkatkan kemampuan pemahaman konsep matematis siswa menjadi lebih baik.

\section{KESIMPULAN}

Terdapat perbedaan kemampuan pemahaman konsep matematis siswa yang pendekatan realistic mathematics education (RME) dengan siswa yang menggunakan pembelajaran konvensional. Selain itu, nilai rata-rata kelas eksperimen lebih tinggi pada nilai rata-rata kelas control walaupun tidak terlalu signifikan. Hal ini berarti bahwa nilai rata-rata kelas eksperimen lebih baik dari pada nilai rata-rata kelas kontrol. Dengan demikian dapat disimpulkan bahwa pendekatan realistic mathematics education (RME) dapat memberikan pengaruh positif terhadap kemampuan pemahaman konsep matematis siswa.

\section{DAFTAR PUSTAKA}

Aan Hendrayana. (2017). Pengaruh Pembelajaran Pendekatan Rigorous Mathematical Thinking (RMT) terhadap Pemahaman Konseptual Matematis Siswa SMP. Jurnal Riset Pendidikan Matematika, 4 (2), 186-199.

Badan Standar Nasional Pendidikan (BNSP). (2006). Model Penilaian Kelas. Jakarta: Depdiknas.

Fadhila El Husna, Fitriani Dwina dan Dewi Murni. (2014). Penerapan Strategi REACT dalam Meningkatkan Kemamupan Pemahaman Konsep Matematika Siswa Kelas X SMAN 1 Batang Anai. Jurnal Pendidikan Matematika, 3 (1), Jurnal Pendidikan Matematika, 3 (2), 26-30. 
Hartono. (2010). Analisis Item Instrumen. Pekanbaru : Zanafa Publishing.

Hayatun Nufus dan Suci Yuniati. (2015). Pengaruh Penerapan Pendekatan Realistic Mathematics Education terhadap Kemampuan Koneksi Matematika Siswa Madrasah Tsanawiyah Pondok Pesantren Darel Hikmah Pekanbaru. Suska Journal of Mathematics Education, 1 (1), 54-59.

Nela Rizka, Hendra Syarifuddin dan Suherman. (2014). Pengaruh Penerapan Strategi Relating, Experiencing, Appliying, Cooperating, Transferring terhadap Kemampuan Pemahaman Konsep Matematika Siswa Kelas X SMAN 2 Payakumbuh. Jurnal Pendidikan Matematika, 3 (2), 4448.

Nur Atika, Zubaidah Amir MZ. (2016). Pengembangan LKS Berbasis Pendekatan RME untuk Menumbuhkembangkan kemampuan berpikir kritis matematis siswa. Suska Journal of Mathematics Education, 2 (2), 103-110.

Prabowo, Agus dan Pramono Sidi. (2010). Potensi PMRI sebagai Inovasi dalam Pembelajaran Matematika", (Program Studi Matematika Universitas Jenderal Sudirman, Universitas Terbuka.

Saleh, Muhammad. (2012). Pembelajaran Kooperatif dengan Pendekatan Pembelajaran Matematika Realistik (PMR), Jurnal Pendidikan Serambi Ilmu, 13 (2).

Saraswati dkk. (2012). Penerapan pembelajaran two stay two stray (TSTS) terhadap kemampuan pemahaman konsep dan minat. Journal of Mathematics Education Unnes.

Siti Nur'aini, Riana Irawati dan Julia. (2016). Pengaruh pendekatan realistic mathematics education (RME) terhadap Kemampuan Pemahaman Matematis dan Kepercayaan Diri Siswa pada Materi Menyederhanakan Pecahan. Jurnal Pena Ilmiah, 1 (1), 691-700.

Suci Yuniati dan Arnida Sari. (2018). Pengembangan Modul Matematika terintegrasi Nilai-Nilai Keislaman melalui Pendekatan Realistic Mathematics Education (RME) di Provinsi Riau, 4 (1), 157-165.

Sugiyono. (2013). Metode Penelitian Pendidikan Pendekatan Kuantitatif, Kualitatif, dan R\&D. Bandung: Alfabeta.

Suharsimi Arikunto. (2011). Dasar-dasar Evaluasi Pendidikan. Yogyakarta: PT Bumi Aksara.

Suherman, Erman dkk. (2003) Common Textbook Strtaegi Pembelajaran Matematika Kontemporer, Bandung: PT Remaja Rosdakarya.

Wahyudin. (2008). Pembelajaran dan Model-model Pembelajaran. Bandung : UPI Press.

Wijaya, Ariyadi. (2012). Pendidikan Matematika Realistik, Yogyakarta: Graha Ilmu. 